\title{
An Analysis of Brand Personality on Brand Loyalty in Frozen Seafood Supermarkets in Ho Chi Minh City
}

\author{
Nguyen ${ }^{1}$, Thi Thanh Thuy ${ }^{1}$ and Quang Thanh ${ }^{2 *}$
}

${ }^{1}$ Safe Seafood and Construction, Ho Chi Minh City, Vietnam

${ }^{2}$ Southern Center of Agricultural Rural Policy and Strategy (SCAP-IPSARD), Ho Chi Minh City, Vietnam

\begin{abstract}
This investigation on frozen seafood brand's personality helps to understand how different variables influence brand loyalty. The research results will contribute to the theory of brand loyalty through understanding the meaning of the factors of brand personality that affect consumer loyalty to the brand. A final sample of 397 observations in Ho Chi Minh City was established. Reliability tests and Exploratory Factor Analysis suggest a model established the impact of brand personality on brand loyalty, basing on five factors of Utility, Creditability, Excitement, Competency, and Sophistication. Regression analysis provides that that Utility, Creditability, Excitement, Competency all have significant impact on brand loyalty. The study offers recommendations to managers of seafood companies, to policy makers in the fields related to seafood sector, to administrators at various level in Ho Chi Minh City, and to customers at supermarkets in Ho Chi Minh City.
\end{abstract}

Keywords: Brand personality; Brand loyalty; Frozen seafood; Supermarkets; Ho chi minh city

\section{Introduction}

During the last 15 years, branding has been recognized in Vietnam as not only as names or origins functioning as identifies to distinguish one product from another. Instead, branding is more in terms of intangible asset. In a recent survey, the local brand names made up half of the 500 most well-known brands in the market. Among the top 10 most famous brands are three local brands (Beer 333, Kinh Do confectionary and Vinamilk). These are in line with the most powerful global names such as CocaCola, Omo, Sunsilk and Honda. Branding turns out to have a considerable influence on customers' behavior, attitude and preference in their buying process. According to Viettrack market research panel [1] interviewing 600 consumers, more than $80 \%$ of consumers in three out of four biggest cities in Vietnam said they seldom switch brands, which is referred to high brand loyalty.

Branding in the seafood sector compared with other food processing sectors has relatively lagged behind. Still, most Vietnamese seafood companies do not understand branding correctly, which has created many misconceptions. Some identify branding with advertising, while others merely think of it as a communication activity without giving heed to consistency in branding execution, distribution channels, or product quality. Without a proper understanding of banding, seafood companies so far have not developed in terms of domestic market. Also, there exist challenges to branding seafood sector consumers in different geographic regions of Vietnam have diversified band personality in terms of diverse buying behaviors and preference.

This research will examine the impact of brand personality on brand loyalty in frozen seafood markets in Ho Chi Minh City (Vietnam). The following section of this paper presents materials and methods. Section 3 is about results and discussion. Section 4 is conclusion and recommendations.

\section{Materials and Methods}

\section{Review of literature and suggested model}

The concept of brand personality is 'one of the most common descriptions in the branding literature' [2]. According to Kassarjian [3], brand personality has enjoyed some popularity and application among advertising practitioners, academic interest in the construct remained limited because its usefulness was delayed by the lack of a uniform definition, structure and empirically valid operationalisation. This changed only after Aaker [4] had developed a general scale which identified the dimensional structure and content of brand personality. Brand personality refers to 'the set of human characteristics associated with a brand' Aaker [4]. Contrary to product-related attributes, which refer to be performance-oriented for customers, brand personality seems to be representative/self-expressive oriented [5]. Moreover, researchers found that brand personality facilitates a consumer to articulate his/her self [6], an ideal self [7], or exact aspects of the self [8] via the use of a brand. Additionally, this concept was the essential determinant of consumer preference and usage [9]. The direct influences included the brand's user imagery, which is defined as 'the set of human characteristics associated with the typical user of a brand'[4].

Thus, brand personality is the set of human personality traits that are both applicable to and relevant for brands [10]. Strong and differentiated brands significantly enhance firm performance [1113] Plummer [14] argued that brand personality might be crucial in understanding brand choice. Indeed, at a time in which consumers consider product quality as a given and competitors can easily copy product characteristics, a strong brand identity and personality are invaluable to build brand equity [15].

Leary and Tangney [16] suggest personality as a good concept to capture the meaning of the self. Tesser and Paulhus [17] argues that personality is a representation of the self. Therefore, personality

*Corresponding author: Quang Thanh, Southern Center of Agricultural Rural Policy and Strategy (SCAP-IPSARD), Ho Chi Minh City, Vietnam; Tel: (84)937105567; E-mail: thanh.ngo@scap.gov.vn

Received December 26, 2015; Accepted January 28, 2016; Published February 06, 2016

Citation: Nguyen, Thuy TT, Thanh Q (2016) An Analysis of Brand Personality on Brand Loyalty in Frozen Seafood Supermarkets in Ho Chi Minh City. J Aquac Res Development. 7: 412. doi:10.4172/2155-9546.1000412

Copyright: $\odot 2016$ Nguyen, et al. This is an open-access article distributed under the terms of the Creative Commons Attribution License, which permits unrestricted use, distribution, and reproduction in any medium, provided the original author and source are credited. 
is used to examine the self. Self-report personality is the perception (consciousness) of the individual himself and it is important in understanding the construction of this individual's self-identity. In relation to the examination of the concept of consumption used-toconstruct-self identities, the metaphors - brand personality and brand relationship - are used to associate with consumer brand loyalty. Aaker [4] measures identified five dimensions of brand personality: sincerity, excitement, competence, sophistication and ruggedness.

In the model, brand personality, following Aaker [4], was characterized by five factors such as sincerity, excitement, competency, ruggedness and sophistication. Customer brand loyalty as dependent variable in a linear regression model that was used to study the significance of each of five brand personality variables. Detailed components of each factors of band personality are listed in (Table 1).

Jacoby and Chestnut [18] provided a conceptual definition of brand loyalty as: (1) biased (i.e. non-random), (2) behavioral response (i.e. purchase), (3) expressed over time, (4) by some decision-making unit, (5) with respect to one or more brands out of a set of such brands, and is a function of psychological (decision-making evaluate) processes. Brand loyalty can be operationalised either based on behavioral, attitudinal or composite approach [18]. Behavioral loyalty has been considered as repeat purchases frequency e.g. Brown [19] or proportion of purchase e.g. Cunningham [20], while attitudinal brand loyalty referred to 'stated preferences, commitment or purchase intentions of the customers'. Brand loyalty is measured by 8 components, which have been developed by Ratchford [21] and we made some adjustments in this dissertation, including: (1) Continued to choose this brand again; (2) This brand is the best choice; (3) Loyal patron of this brand; (4) Recommend this brand to others; (5) Intention to purchase this brand again; (6) This brand is the first \& prefer choice; (7) Speak positively about this brand; (8) Encourage others to buy this brand.

The researcher will apply the conceptual model of brand personality dimensions and brand loyalty that were employed by Venkateswaran et al. [22] as shown in (Figure 1).

The following hypotheses would be tested:

(1). Hypothesis 1 (H1): Brand personality dimension Sincerity will lead to brand loyalty.

(2). Hypothesis 2 (H2): Brand personality dimension Excitement will lead to brand loyalty.

(3). Hypothesis 3 (H3): Brand personality dimension Competence will lead to brand loyalty.

(4). Hypothesis 4 (H4): Brand personality dimension Sophistication will lead to brand loyalty.

(5). Hypothesis 5 (H5): Brand personality dimension Ruggedness will lead to brand loyalty.

\section{Methods}

Population, sampling of the study and data collection: The target population for this study is mainly composed of customers who buy frozen seafood at supermarkets in Ho Chi Minh City.

As convenience samples are generally the cheapest and easiest to conduct. Convenience sampling is most often used during the exploratory phase of a research project and is perhaps the best way of getting some basic information quickly and efficiently. So, convenience sampling was used to collect data of 400 customers who are distributed in accordance with the percentage of big supermarkets located in Ho Chi Minh City.

The self-completion questionnaires were distributed to customers who were shopping at listed supermarkets in Ho Chi Minh City in July of 2015. In order to have a higher response rate, customers were given the questionnaires and were requested to complete and return the questionnaires in 30 minutes. After receiving the answered questionnaire, the researcher carefully checked each questionnaire and rejected ones that hah more than one missing value and not selecting all " 1 " or all " 5 " for more than two factors. The researcher further released more questionnaires to customers so as to reach the total of 400 customers as designed. Out of 867 respondents 648 ones returned the questionnaire, for a response rate of 75.0 percent. From 648 observations, 397 respondents were usable.

Measurement scale, reliability analysis, efa and regression analysis: A 5-point Likert type scale ranging from (1) (Strongly Disagree) to (5) (Strongly Agree) is applied and all measurements were carried out as stated in the following sections.

Cronbach Alpha Reliability Analysis was used to test the reliability of the measurement scales. The scales are reliable when Cronbach's Alpha coefficient of each scale is bigger 0.7 [23]. In this study, the accepted Item-total Correlation Statistics of 0.300 is used for considering the correlations between a scale item and the sum of all the scale items. Items which are correlated with the other items of the group less than 0.300 will be deleted from the next analysis.

\begin{tabular}{|c|c|c|}
\hline No & Dimensions & Variables \\
\hline 1 & Sincerity & $\begin{array}{l}\text { Quality, Comfortable, Durability, Reality, Benefits, Original, } \\
\text { Friendly, Honest }\end{array}$ \\
\hline 2 & Excitement & $\begin{array}{l}\text { Style, Special Occasion, Feeling, Feel Different, Up To } \\
\text { Date, Independent, Unique }\end{array}$ \\
\hline 3 & Competence & $\begin{array}{l}\text { Fashionable, Corporate, Leader, Confident, Reliability, } \\
\text { Affinity, Faithfulness, }\end{array}$ \\
\hline 4 & Ruggedness & $\begin{array}{l}\text { Rough \& Touch, Frequent Washing, Modern, Masculine, } \\
\text { Out Side Appearance }\end{array}$ \\
\hline 5 & Sophistication & $\begin{array}{l}\text { User Feeling, Upper Class, Glamorous, Smooth, } \\
\text { Charming, User's Personality, Consumer Preference }\end{array}$ \\
\hline
\end{tabular}

Table 1: Details of brand personality components.

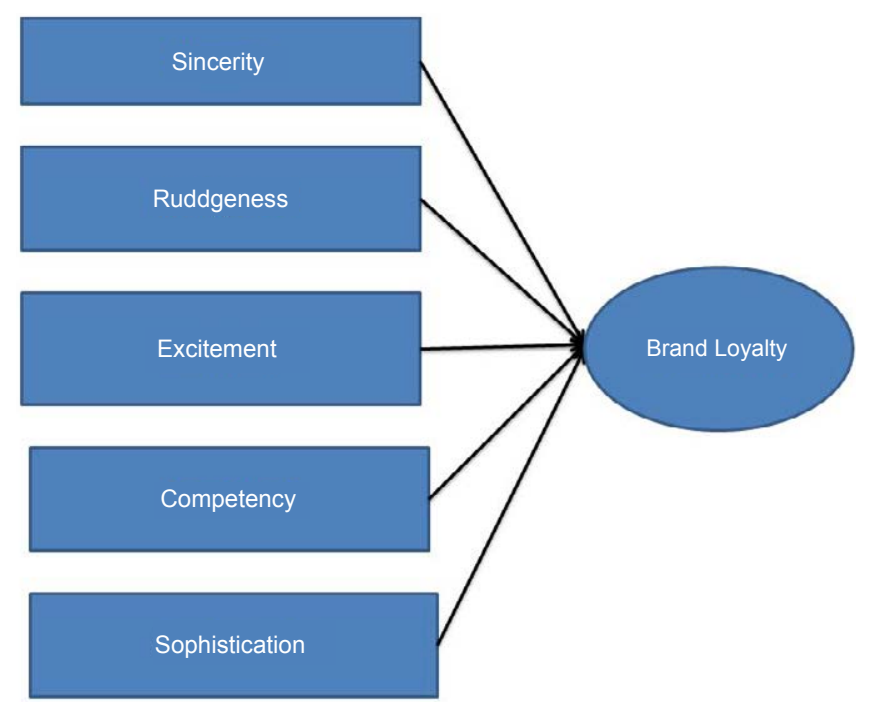

Figure 1: Conceptual model of brand personality dimensions and brand loyalty. 
The research model has six group of items (variables) with 36 observed variables, affecting brand loyalty in frozen seafood in Ho Chi Minh City. After testing the reliability of the scale item groups, the researcher conducted exploratory factor analysis (EFA) through the Principal Axis Factoring, using the Varimax rotation method to analyze 24 observed independent variables, and the Principal component analysis for 7 dependent components. In addition, the researcher used KMO (Kaiser-Meyer-Olkin) and Barlett's test method to measure the compatibility of the survey and the results.

The multiple regression formula will be:

$\mathrm{Y}=\alpha+\beta_{1} \mathrm{X}_{1}+\beta_{2} \mathrm{X}_{2}+\beta_{3} \mathrm{X}_{3}+\beta_{4} \mathrm{X}_{4}+\beta_{5} \mathrm{X}_{5}+\varepsilon$

Where in: $Y$ : is the dependent variable referred to brand loyalty

a: is constant

$\beta$ : is called the vector of beta weight, standardized regression coefficient, or beta coefficient

$\mathrm{X}$ : is the vector of predictors of brand characteristics including: Sincerity, Excitement, Ruggedness, Competence, and Sophistication

$\varepsilon:$ is the residual

\section{Results and Discussion}

\section{Description analysis}

Descriptive analysis of the respondent profile is shown in Table 2. Out of 384 respondents, more than half of these respondents were female (66.5 percent) and (30.2) percent were male. Most of the respondents ( 47.1 percent) were between 22 and 29 years-old. The remaining 26.7 percent, 9.6 percent, 7.8 percent, and 5.0 percent were between 30 and 40 years-old, between 41 and 50 years, less than 20 years-old, and over the age of 50 years respectively. In terms of marital status, it comprised 36.5 percent of married, 52.1 percent of single people and 3.3 percent of others. The percentage of the respondents who had high school education was 28.7 percent, college/university education was 64.5 percent and 3.3 percent of others. In terms of occupation, $7.8 \%$ were students, $43.6 \%$ were office staff, $10.8 \%$ were common laborers/workers, $8.3 \%$ were merchants, $4.0 \%$ were at the managerial level, and 20.90 percent were other jobs. Concerning the monthly income, 29.5 percent received less than 5 million VND, 52.1 percent reported an income of between 5 and 10 million VND, 8.6 percent received an income of between 11 to 15 million VND, 1.0 percent received an income of between 16 to 20 million VND, 1.5 percent received an income of between 20 to 30 million VND, and 1.3 percent earned more than 30 million VND (Table 2).

Out of 397 respondents, 27.2 percent of respondents most often buy Cau Tre's products, 23.7 percent with Tan Viet Sinh's, 21.4 percent with Coopmart's, 6.0 percent with VinhHoan's, 4.5 percent with Agifish, and 9.8 percent with other seafood brands.

\section{Reliability test and efa}

Table 3 shows the results of Cronbach's alpha of factors, namely: Sincerity, Excitement, Competency, Ruggedness, Sophistication, and Loyalty. The values of Cronbach's alpha of Ruggedness were 0.495 and thus less than 0.7 and dropped from the analysis. All the remained values of Cronbach's alpha were from 0.722 (Sophistication) to 0.843 (Loyalty). The reliability of the remained measures thus can be attained (Table 3).

Table 4 shows that the final alpha values of the overall constructs were higher than the alpha if item deleted. All the values of Cronbach's alpha were from 0.913 to 0.916 . Corrected Item-Total Correlation values of all variables were now over 0.3 then the item will make a good component of a summated rating scale. All of those meant the data was good for conducting exploratory factor analysis (Table 4).

\begin{tabular}{|c|c|c|c|c|}
\hline & Frequency & Percent & Valid Percent & Cum. Percent \\
\hline \multicolumn{5}{|l|}{ Gender } \\
\hline Male & 120 & 30.2 & 31.2 & 31.2 \\
\hline Female & 264 & 66.5 & 68.6 & 99.7 \\
\hline missing & 1 & 0.3 & 0.3 & 100.0 \\
\hline Total & 385 & 97.0 & 100.0 & \\
\hline \multicolumn{5}{|c|}{ Age } \\
\hline Less than 22 & 31 & 7.8 & 8.1 & 8.1 \\
\hline From 22 to 29 & 187 & 47.1 & 49.0 & 57.1 \\
\hline From 30 to 40 & 106 & 26.7 & 27.7 & 84.8 \\
\hline From 41 to 50 & 38 & 9.6 & 9.9 & 94.8 \\
\hline Over 50 & 20 & 5.0 & 5.2 & 100.0 \\
\hline Total & 382 & 96.2 & 100.0 & \\
\hline \multicolumn{5}{|c|}{ Marital status } \\
\hline Married & 145 & 36.5 & 39.7 & 39.7 \\
\hline Single & 207 & 52.1 & 56.7 & 96.4 \\
\hline Divorced & 12 & 3.0 & 3.3 & 99.7 \\
\hline Other & 1 & 0.3 & 0.3 & 100.0 \\
\hline Total & 365 & 91.9 & 100.0 & \\
\hline \multicolumn{5}{|c|}{ Education level } \\
\hline Primary school & 5 & 1.3 & 1.3 & 1.3 \\
\hline Secondary school & 114 & 28.7 & 29.8 & 31.1 \\
\hline College/university & 256 & 64.5 & 66.8 & 97.9 \\
\hline No degree & 8 & 2.0 & 2.1 & 100.0 \\
\hline Total & 383 & 96.5 & 100.0 & \\
\hline \multicolumn{5}{|c|}{ Occupation } \\
\hline Students & 31 & 7.8 & 8.2 & 8.2 \\
\hline Office staff & 173 & 43.6 & 45.6 & 53.8 \\
\hline Merchant & 33 & 8.3 & 8.7 & 62.5 \\
\hline Workers & 43 & 10.8 & 11.3 & 73.9 \\
\hline Manager & 16 & 4.0 & 4.2 & 78.1 \\
\hline Housewife & 21 & 5.3 & 5.5 & 83.6 \\
\hline Other & 62 & 15.6 & 16.4 & 100.0 \\
\hline Total & 379 & 95.5 & 100.0 & \\
\hline \multicolumn{5}{|c|}{ Income level } \\
\hline $\begin{array}{c}\text { Less than } 5 \text { mill. } \\
\text { VND }\end{array}$ & 117 & 29.5 & 31.4 & 31.4 \\
\hline $\begin{array}{c}\text { From } 5 \text { to } 10 \text { mill. } \\
\text { VND }\end{array}$ & 207 & 52.1 & 55.5 & 86.9 \\
\hline $\begin{array}{c}\text { From } 11 \text { to } 15 \text { mill. } \\
\text { VND }\end{array}$ & 34 & 8.6 & 9.1 & 96.0 \\
\hline $\begin{array}{c}\text { From } 16 \text { to } 20 \text { mill. } \\
\text { VND }\end{array}$ & 4 & 1.0 & 1.1 & 97.1 \\
\hline $\begin{array}{c}\text { From } 20 \text { to } 30 \text { mill. } \\
\text { VND }\end{array}$ & 6 & 1.5 & 1.6 & 98.7 \\
\hline Over 30 mill. VND & 5 & 1.3 & 1.3 & 100.0 \\
\hline Total & 373 & 94.0 & 100.0 & \\
\hline
\end{tabular}

Table 2: Statistic description of response' characteristics. 
Citation: Nguyen, Thuy TT, Thanh Q (2016) An Analysis of Brand Personality on Brand Loyalty in Frozen Seafood Supermarkets in Ho Chi Minh City. J Aquac Res Development. 7: 412. doi:10.4172/2155-9546.1000412

Page 4 of 8

\begin{tabular}{|c|c|c|}
\hline Facets & Cronbach's Alpha & Number of items \\
\hline Sincerity & 0.819 \\
\hline Excitement & 0.813 & 9 \\
\hline Competency & 0.736 & \\
\hline Ruggedness & 0.495 & \\
\hline Sophistication & 0.722 & \\
\hline Loyalty & 0.843 & \\
\hline
\end{tabular}

Table 3: Reliability test, all factors.

\begin{tabular}{|c|c|c|c|c|}
\hline Component & $\begin{array}{c}\text { Scale Mean if Item } \\
\text { Deleted }\end{array}$ & $\begin{array}{l}\text { Scale Variance if } \\
\text { item deleted }\end{array}$ & $\begin{array}{c}\text { Corrected Item-Total } \\
\text { Correlation }\end{array}$ & $\begin{array}{l}\text { Cronbach's Alpha if } \\
\text { Item Deleted }\end{array}$ \\
\hline I will choose this brand again & 104.27 & 161.510 & 0.567 & 0.913 \\
\hline Loyal patron of this brand & 104.54 & 160.534 & 0.547 & 0.914 \\
\hline Recommend this brand to others & 104.29 & 161.772 & 0.560 & 0.914 \\
\hline Intention to purchase this brand again & 104.26 & 162.148 & 0.577 & 0.913 \\
\hline This brand is the first \& prefer choice & 104.58 & 160.046 & 0.587 & 0.913 \\
\hline Speak positively about this brand & 104.29 & 162.699 & 0.548 & 0.914 \\
\hline Encourage others to buy this brand & 104.38 & 162.044 & 0.543 & 0.914 \\
\hline I choose brand $X$ because of its quality & 104.53 & 164.342 & 0.461 & 0.915 \\
\hline I choose brand $X$ because its products are easy to process & 104.26 & 165.112 & 0.382 & 0.916 \\
\hline $\begin{array}{l}\text { I choose brand } X \text { because its products can be stored with high } \\
\text { quality }\end{array}$ & 104.49 & 163.167 & 0.481 & 0.915 \\
\hline $\begin{array}{l}\text { I choose brand } X \text { because its products are as exact as } \\
\text { advertisement }\end{array}$ & 104.50 & 163.737 & 0.484 & 0.915 \\
\hline I choose brand $X$ because its products bring nutrition & 104.52 & 161.497 & 0.474 & 0.915 \\
\hline I choose brand $\mathrm{X}$ because its products bring safety & 104.33 & 163.836 & 0.486 & 0.915 \\
\hline I choose brand $\mathrm{X}$ because its products are original & 104.30 & 164.908 & 0.364 & 0.916 \\
\hline I choose brand $X$ because its products bring friendly feelings & 104.29 & 164.237 & 0.431 & 0.915 \\
\hline I choose brand $X$ because the company proves its sincerity & 104.42 & 162.545 & 0.520 & 0.914 \\
\hline I choose brand $X$ because of its style & 104.58 & 160.733 & 0.523 & 0.914 \\
\hline $\begin{array}{l}\text { I choose brand } \mathrm{X} \text { because its products are suitable for special } \\
\text { occasion }\end{array}$ & 104.92 & 161.236 & 0.459 & 0.915 \\
\hline I choose brand $X$ because its products bring good passion & 104.83 & 160.152 & 0.541 & 0.914 \\
\hline I choose brand $X$ because its products give difference & 104.86 & 161.197 & 0.522 & 0.914 \\
\hline I choose brand $X$ because its products are up-to-date & 104.65 & 162.880 & 0.411 & 0.916 \\
\hline I choose brand $X$ because its products are unique & 104.97 & 158.246 & 0.551 & 0.914 \\
\hline I choose brand $X$ because its products are good packing design & 104.35 & 161.627 & 0.485 & 0.915 \\
\hline I choose brand $X$ because its products are leading in the field & 104.63 & 159.867 & 0.542 & 0.914 \\
\hline I choose brand $\mathrm{X}$ because its products bring confidence & 104.28 & 161.506 & 0.520 & 0.914 \\
\hline I choose brand $X$ because its products are affordable & 104.20 & 162.721 & 0.471 & 0.915 \\
\hline I choose brand $X$ because its products are of affinity & 104.60 & 160.906 & 0.502 & 0.914 \\
\hline I choose brand $X$ because its products bring good feelings & 104.57 & 162.983 & 0.436 & 0.915 \\
\hline I choose brand $X$ because its products are upper class & 104.67 & 163.072 & 0.428 & 0.915 \\
\hline I choose brand $X$ because its products suit my characteristics & 104.52 & 163.187 & 0.461 & 0.915 \\
\hline I choose brand $X$ because its products are my preference & 104.65 & 163.21 & 0.41 & 0.916 \\
\hline Cronbach's Alpha & & & & 0.917 \\
\hline
\end{tabular}

Table 4: Reliability test of various dimension factors.

The EFA results for the factor Sincerity in Table 5 showed that the KMO values of this factor were bigger than 0.793 at the Barlett's Test of Significance $0.000<0.01$. The EFA results for the factor Excitement shows that the KMO values of this factor were bigger than 0.769 at the Barlett's Test of Significant $0.000<0.01$. The EFA results for the factor Competency shows that the KMO values of this factor were bigger than 0.772 at the Barlett's Test of Significance $0.000<0.01$. The EFA results for the factor Sophistication showed that the KMO values of this factor were bigger than 0.754 at the Barlett's Test of Significance $0.000<0.01$. The EFA results for the factor Brand Loyalty shows that the $\mathrm{KMO}$ values of this factor were bigger than 0.848 at the Barlett's
Test of Significance $0.000<0.01$. Therefore, all the results satisfied the conditions of EFA (Table 5).

Table 6 shows that there are two components of the factor Sincerity, Eigenvalues $>1.0$ which is a common criterion for a factor useful. Cumulative: 56.366 is satisfactory. This factor Sincerity is divided into two sub-factors, the first one includes components C3.1.4 ("I choose brand X because its products are as exact as advertisement"), C3.1.1 ("I choose brand X because of its quality"), C3.1.5 ("I choose brand $\mathrm{X}$ because its products bring nutrition"), C3.1.6 ("I choose brand X because its products bring safety"), and C3.1.2 ("I choose brand X because its products are easy to process"), the second one comprises of 


\begin{tabular}{|c|c|c|c|c|c|}
\hline Test & Sincerity & Excitement & Competency & Sophistication & Brand Loyalty \\
\hline Kaiser-Meyer-Olkin Measure of Sampling Adequacy & 0.793 & 0.769 & 0.772 & 0.754 & 0.848 \\
\hline Bartlett's Test of Sphericity -Approx. Chi-Square & 1327.212 & 928.715 & 380.178 & 297.162 & 953.099 \\
\hline df & 36 & 15 & 10 & 6 & 21 \\
\hline Sig. & 0.000 & 0.000 & 0.000 & 0.000 & 0.000 \\
\hline
\end{tabular}

Table 5: Results of KMO and Barlett's test, all factors.

\begin{tabular}{|c|c|c|c|c|c|c|}
\hline \multirow{2}{*}{ Facet } & \multicolumn{3}{|c|}{ Initial Eigenvalues } & \multicolumn{3}{|c|}{ Extraction Sums of Squared Loadings } \\
\hline & Total & $\%$ of Variance & Cum. \% & Total & $\%$ of Variance & Cum. \% \\
\hline \multicolumn{7}{|l|}{ Sincerity } \\
\hline Component \# 1 & 3.802 & 42.239 & 42.239 & 3.802 & 42.239 & 42.239 \\
\hline Component \# 2 & 1.271 & 14.127 & 56.366 & 1.271 & 14.127 & 56.366 \\
\hline \multicolumn{7}{|l|}{ Excitement } \\
\hline Component \# 1 & 3.140 & 52.335 & 52.335 & 3.140 & 52.335 & 52.335 \\
\hline \multicolumn{7}{|l|}{ Competency } \\
\hline Component \# 1 & 2.439 & 48.784 & 48.784 & 2.439 & 48.784 & 48.784 \\
\hline \multicolumn{7}{|l|}{ Sophistication } \\
\hline Component \# 1 & 2.191 & 54.781 & 54.781 & 2.191 & 54.781 & 54.781 \\
\hline \multicolumn{7}{|l|}{ Brand Loyalty } \\
\hline Component \# 1 & 3.629 & 51.849 & 51.849 & 3.629 & 51.849 & 51.849 \\
\hline
\end{tabular}

Table 6: Total Variance Explained, all factors.

C3.1.7 ("I choose brand X because its products are original"), C3.1.9 ("I choose brand X because the company proves its sincerity"), and C3.1.8 ("I choose brand X because its products bring friendly feelings"). Based on the similar features, the first group can be named as Utility, and the second as Creditability.

Table 6 also shows that there is one component of the factor Excitement, Eigenvalues $>1.0$ which is a common criterion for a factor useful. Cumulative: 52.335 is satisfactory; there is one component of the factor Competency, Eigenvalues $>1.0$ which is a common criterion for a factor useful. Cumulative: 48.784 is satisfactory; there is one component of the factor Sophistication, Eigenvalues $>1.0$ which is a common criterion for a factor useful. Cumulative: 54.781 is satisfactory; and there is one component of the factor Brand Loyalty, Eigenvalues $>1.0$ which is a common criterion for a factor useful. Cumulative: 51.849 is satisfactory (Table 6).

Table 7 shows that the scale coefficients of the factor Sincerity were satisfactory $(>0.5)$. The smallest is variable "I choose brand $\mathrm{X}$ because its products are easy to process" $(0.540)$; the scale coefficients of the factor Excitement were satisfactory $(>0.5)$. The smallest is variable "I choose brand X because its products are up-to-date" (0.574); the scale coefficients of the factor Competency were satisfactory $(>0.5)$. The smallest is variable "I choose brand X because its products are of affinity" (0.660); the scale coefficients of the factor Sophistication were satisfactory $(>0.5)$. The smallest is variable "I choose brand X because its products are my preference" (0.689); the scale coefficients of the factor Brand Loyalty were satisfactory $(>0.5)$. The smallest is variable "Loyal patron of this brand" (0.681) (Table 7).

\section{Regression analysis and hypothesis testing}

Multi-regression analyses were conducted to examine the relationship between each item from Item C3.1.1 to Item C3.6.8 in the research questionnaire, which is about customer's loyalty various potential predictors as the factors of Utility, Creditability, Excitement, Competency, and Sophistication.

The final multiple regression model with all four predicators in Table 8 produced $\mathrm{R}^{2}$ adjusted $=0.52$, expressing that the model collected from ANOVA has accounted for $52.0 \%$ of the variance. The $\mathrm{F}$ value is 85.800 , and $p$ is $<0.01$, which shows that the model is statistically significant at $1 \%$ level (Table 8 ).

As can be seen in Table 9 below, four remained factors now have significant positive regression weights at $1 \%$ level, with 0.242 for the factor of Utility, 0.134 for the factor of Creditability, 0.218 for the factor of Excitement, and 0.356 for the factor Competency (Table 9).

Hypothesis 1, which predicted that Brand personality dimension Sincerity will lead to brand loyalty. EFA suggests that Sincerity is divided into two components: Utility and Creditability. Therefore, the two respective hypotheses are:

Hypothesis 1a: Brand personality dimension Utility will lead to brand loyalty

Hypothesis 1b: Brand personality dimension Creditability will lead to brand loyalty

Hypothesis 1a, which hypothesized that brand personality dimension Utility will lead to brand loyalty, is accepted $(t=5.923, p$ $<0.01$ ). Thus, it is concluded that brand personality dimension Utility will lead to brand loyalty.

Hypothesis 1b, which hypothesized that brand personality dimension Creditability will lead to brand loyalty, is accepted ( $t=$ $3.216, \mathrm{p}<0.01)$. Thus, it is concluded that brand personality dimension Creditability will lead to brand loyalty.

Hypothesis 2, which hypothesized that Brand personality dimension Excitement will lead to brand loyalty, is accepted $(t=5.269$, $\mathrm{p}<0.01)$. Therefore, Brand personality dimension Excitement will lead to brand loyalty.

Hypothesis 3, which anticipated that Brand personality dimension Competence will lead to brand loyalty, is accepted $(t=8.185, \mathrm{p}<0.01)$. Thus, Brand personality dimension Competence will lead to brand loyalty.

Hypothesis 4, which expected that Brand personality dimension Sophistication will lead to brand loyalty, is rejected $(t=0.249, \mathrm{p}>0.05)$.

Hypothesis 5, which supposed that Brand personality dimension 


\begin{tabular}{|c|c|c|}
\hline & Component & \\
\hline & 1 & 2 \\
\hline \multicolumn{3}{|l|}{ Sincerity } \\
\hline $\begin{array}{l}\text { I choose brand } X \text { because its products are as exact as } \\
\text { advertisement }\end{array}$ & 0.863 & \\
\hline I choose brand $X$ because of its quality & 0.851 & \\
\hline I choose brand $X$ because its products bring nutrition & 0.727 & \\
\hline $\begin{array}{l}\text { I choose brand } X \text { because its products can be stored } \\
\text { with high quality }\end{array}$ & 0.633 & \\
\hline I choose brand $X$ because its products bring safety & 0.583 & \\
\hline $\begin{array}{l}\text { I choose brand } X \text { because its products are easy to } \\
\text { process }\end{array}$ & 0.540 & \\
\hline I choose brand $X$ because its products are original & & 0.761 \\
\hline $\begin{array}{l}\text { I choose brand } X \text { because the company proves its } \\
\text { sincerity }\end{array}$ & & 0.715 \\
\hline $\begin{array}{l}\text { I choose brand } X \text { because its products bring friendly } \\
\text { feelings }\end{array}$ & & 0.708 \\
\hline \multicolumn{3}{|l|}{ Excitement } \\
\hline I choose brand $X$ because its products are unique & 0.831 & \\
\hline I choose brand $X$ because its products give difference & 0.826 & \\
\hline $\begin{array}{l}\text { I choose brand } X \text { because its products are suitable for } \\
\text { special occasion }\end{array}$ & 0.701 & \\
\hline I choose brand $X$ because of its style & 0.689 & \\
\hline $\begin{array}{l}\text { I choose brand } X \text { because its products bring good } \\
\text { passion }\end{array}$ & 0.686 & \\
\hline I choose brand $X$ because its products are up-to-date & 0.574 & \\
\hline \multicolumn{3}{|l|}{ Competency } \\
\hline $\begin{array}{l}\text { I choose brand } X \text { because its products are good } \\
\text { packing design }\end{array}$ & 0.759 & \\
\hline $\begin{array}{l}\text { I choose brand X because its products are leading in } \\
\text { the field }\end{array}$ & 0.728 & \\
\hline $\begin{array}{l}\text { I choose brand } \mathrm{X} \text { because its products bring } \\
\text { confidence }\end{array}$ & 0.673 & \\
\hline I choose brand $X$ because its products are affordable & 0.668 & \\
\hline$I$ choose brand $X$ because its products are of affinity & 0.660 & \\
\hline \multicolumn{3}{|l|}{ Sophistication } \\
\hline I choose brand $X$ because its products are upper class & 0.796 & \\
\hline $\begin{array}{l}\text { I choose brand } \mathrm{X} \text { because its products suit my } \\
\text { characteristics }\end{array}$ & 0.751 & \\
\hline $\begin{array}{l}\text { I choose brand } X \text { because its products bring good } \\
\text { feelings }\end{array}$ & 0.721 & \\
\hline $\begin{array}{l}\text { I choose brand } \mathrm{X} \text { because its products are my } \\
\text { preference }\end{array}$ & 0.689 & \\
\hline \multicolumn{3}{|l|}{ Brand Loyalty } \\
\hline Intention to purchase this brand again & 0.751 & \\
\hline Encourage others to buy this brand & 0.748 & \\
\hline Recommend this brand to others & 0.740 & \\
\hline This brand is the first \& prefer choice & 0.717 & \\
\hline Speak positively about this brand & 0.709 & \\
\hline I will choose this brand again & 0.691 & \\
\hline Loyal patron of this brand & 0.681 & \\
\hline
\end{tabular}

Table 7: Factor analysis, all factors.

Ruggedness will lead to brand loyalty, is rejected since it failed reliability test.

\section{Discussions}

Table 10 presents a statistical summary of factors, namely Utility, Creditability, Excitement and Competence. For specific strategy toward brand personality, with regarding to factor Competence, managers should pay more attention to factors that less than the average values of all factors (3.50) such as leading, and affinity. With regarding to factor Utility, managers should pay more attention to factors that less than the average values of all factors (3.50) such as quality, store with high quality, exact as advertised, and nutritional. With regarding to factor Excitement, managers should pay more attention to factors that less than the average values of all factors (3.50) such as style, suitable, good passion, being different, up to date, independent, and unique (Table $10)$.

Table 10 shows that with respect to factor Competence, most influent features are well-designed, confidence of delivery, and affordable; with respect to factor Utility, most influent features are easy to process, and safe; with respect to factor Excitement, most influent features are independent; with respect to factor Creditability, most influent features are friendly, original, and sincerity proven.

Table 10 also shows that with respect to factor Competence, features need to improved are leading, and affinity; with respect to factor Utility, features need to improved are quality, store with high quality, exact as advertised, and nutritional; with respect to factor Excitement, features need to improved are style, suitable, good passion, being different, up to date, independent, and unique.

Table 11 presents a statistical summary of Brand Loyalty. Features that gained high assessment (larger than the average) are "I will choose this brand again", "This brand is the best choice", "Recommend this brand to others", "Intention to purchase this brand again", and "Speak positively about this brand". Features that gained low assessment (from and below the average) are "Loyal patron of this brand", "This brand is the first \& prefer choice", and "Encourage others to buy this brand" (Table 11).

\section{Conclusion and Recommendations}

\section{Conclusion}

It is clear that Utility, Creditability, Excitement, Competency all have significant impact on brand loyalty. Therefore, as strategy as a whole, managers can focus on these factors so as to keep customers' loyalty. The priorities of targets are: Competency, Utility, Excitement, and Creditability.

\section{Recommendations}

To managers of seafood companies: First, managers should keep their products in terms of the following four groups of factors: Competency, Utility, Excitement, and Creditability. These factors are crucial to the management to set strategy and objectives to capture

\begin{tabular}{|c|c|c|c|c|}
\hline Model & $\mathbf{R}$ & $\mathbf{R}$ Square & Adjusted R Square & $\begin{array}{c}\text { Std. Error of the } \\
\text { Estimate }\end{array}$ \\
\hline 1 & 0.725 & 0.525 & 0.520 & 0.690 \\
\hline \multicolumn{4}{|c}{ Table 8: Model Summary. }
\end{tabular}

\begin{tabular}{|c|c|c|c|c|c|c|c|}
\hline & Model & $\begin{array}{c}\text { Standard } \\
\text { coefficient }\end{array}$ & $\mathbf{t}$ & Sig & \multicolumn{2}{|c|}{$\begin{array}{c}95.0 \% \\
\text { Confidence } \\
\text { Interval for B }\end{array}$} & \multicolumn{2}{|c|}{$\begin{array}{c}\text { Collinearity } \\
\text { Statistics }\end{array}$} \\
\cline { 3 - 8 } & & & $\begin{array}{c}\text { Lower } \\
\text { Bound }\end{array}$ & $\begin{array}{c}\text { Upper } \\
\text { Bound }\end{array}$ & Tolerence & VVIF \\
\hline Constant & & 0.126 & 0.900 & -0.064 & 0.073 & & \\
\hline Utility & 0.242 & 5.923 & 0.000 & 0.162 & 0.322 & 0.729 & 1.372 \\
\hline Creditability & 0.134 & 3.216 & 0.001 & 0.052 & 0.214 & 0.707 & 1.414 \\
\hline Excitement & 0.218 & 5.269 & 0.000 & 0.136 & 0.299 & 0.714 & 1.400 \\
\hline Competency & 0.356 & 8.185 & 0.000 & 0.269 & 0.438 & 0.647 & 1.546 \\
\hline
\end{tabular}

Table 9: Coefficients of refined model. 


\begin{tabular}{|c|c|c|c|c|}
\hline Factor & Question & Mean & Std. Dev. & $\mathbf{N}$ \\
\hline \multicolumn{5}{|l|}{ Utility } \\
\hline C3.1.1 & I choose the brand because of its quality & 3.46 & 0.668 & 397 \\
\hline C3.1.2 & $\begin{array}{l}\text { I choose the brand because its products are } \\
\text { easy to process }\end{array}$ & 3.73 & 0.726 & 397 \\
\hline C3.1.3 & $\begin{array}{l}\text { I choose the brand because its products } \\
\text { can be stored with high quality }\end{array}$ & 3.49 & 0.734 & 397 \\
\hline C3.1.4 & $\begin{array}{l}\text { I choose the brand because its products are } \\
\text { as exact as advertisement }\end{array}$ & 3.48 & 0.684 & 397 \\
\hline C3.1.5 & $\begin{array}{l}\text { I choose the brand because its products } \\
\text { bring nutrition }\end{array}$ & 3.46 & 0.866 & 397 \\
\hline C3.1.6 & $\begin{array}{l}\text { I choose the brand because its products } \\
\text { bring safety }\end{array}$ & 3.65 & 0.679 & 397 \\
\hline \multicolumn{5}{|c|}{ Creditability } \\
\hline C3.1.7 & $\begin{array}{l}\text { I choose the brand because its products } \\
\text { are original }\end{array}$ & 3.69 & 0.770 & 397 \\
\hline C3.1.8 & $\begin{array}{l}\text { I choose the brand because its products } \\
\text { bring friendly feelings }\end{array}$ & 3.70 & 0.718 & 397 \\
\hline C3.1.9 & $\begin{array}{l}\text { I choose the brand because the company } \\
\text { proves its sincerity }\end{array}$ & 3.56 & 0.724 & 397 \\
\hline \multicolumn{5}{|c|}{ Excitement } \\
\hline C3.2.1 & I choose the brand because its style & 3.40 & 0.850 & 396 \\
\hline C3.2.2 & $\begin{array}{l}\text { I choose the brand because its products are } \\
\text { suitable for special occasion }\end{array}$ & 3.06 & 0.912 & 396 \\
\hline C3.2.3 & $\begin{array}{l}\text { I choose the brand because its products } \\
\text { bring good passion }\end{array}$ & 3.15 & 0.861 & 396 \\
\hline C3.2.4 & $\begin{array}{l}\text { I choose the brand because its products } \\
\text { give difference }\end{array}$ & 3.12 & 0.817 & 396 \\
\hline C3.2.5 & $\begin{array}{l}\text { I choose the brand because its products are } \\
\text { up-to-date }\end{array}$ & 3.33 & 0.865 & 396 \\
\hline C3.2.6 & $\begin{array}{l}\text { I choose the brand because its products } \\
\text { can be processed independently }\end{array}$ & 3.81 & 0.746 & 396 \\
\hline C3.2.7 & $\begin{array}{l}\text { I choose the brand because its products } \\
\text { are unique }\end{array}$ & 3.01 & 0.973 & 396 \\
\hline \multicolumn{5}{|c|}{ Competence } \\
\hline C3.3.1 & $\begin{array}{l}\text { I choose the brand because its products are } \\
\text { well-designed }\end{array}$ & 3.64 & 0.838 & 396 \\
\hline C3.3.2 & $\begin{array}{l}\text { I choose the brand because its products are } \\
\text { leading in the field }\end{array}$ & 3.35 & 0.878 & 396 \\
\hline C3.3.3 & $\begin{array}{l}\text { I choose the brand because its products } \\
\text { bring confidence }\end{array}$ & 3.70 & 0.796 & 396 \\
\hline C3.3.4 & $\begin{array}{l}\text { I choose the brand because its products are } \\
\text { affordable }\end{array}$ & 3.79 & 0.777 & 396 \\
\hline \multirow[t]{2}{*}{ C3.3.5 } & $\begin{array}{l}\text { I choose the brand because its products are } \\
\text { of affinity }\end{array}$ & 3.38 & 0.865 & 396 \\
\hline & Average & 3.50 & & \\
\hline
\end{tabular}

Table 10: Statistical summary of refined factors.

the consumers' interest, each component of the factors has a distinct impact, extent and the impact varies from time to time, in each group of subjects or other targets each other. Therefore, managers can use as a basis for selection of the objects, the elements should focus on investment depending on the development stage, specific objectives and strategies to match with their own products and brands.

Second, according to the results of the analysis, the Competency factor should be the most important and the most strongly correlated with Brand Loyalty. This feature is consistent with the current situation; consumers usually buy seafood products that are good packing design, leading, confidence of delivery, affordable, and affinity. This means that they always consider the brand/the company first before buying something.

Third, the Utility factors such as quality, easy to process, durability, exact as advertised, nutritional, and safe, according to the analysis results also significantly influence Brand Loyalty. This means that customers highly consider the quality of seafood products when buying, especially during the increasing escalation of prices, safety and health. Communication programs such as advertising, public relations, promotions should focus on these important factors.

Fourth, Excitement factors such as originality, friendliness, proven sincerity, according to the analysis results also, significantly influence Brand Loyalty. This infers that customers highly consider the behavior that a firm presents in the market when making purchases.

Fifth, Creditability factors such as style, suitability, good passion, being different, up to date, independent, and unique, according to the analysis results also significantly influence Brand Loyalty. This means that customers give high creditability to a firm that maintains its unique characteristics in the market.

Sixth, the analysis also indicates that although not significantly affecting Brand Loyalty but Sophistication is an important factor crucial to the success of the brand strategy. Elements such as bring good feelings, upper class, suitable for customers' characteristics, and customers' preference are key determinants for customers' decisions to buy. Communications programs such as advertising, public relations, promotions should take these humanitarian features into account.

Seventh, for a strategy towards Brand Loyalty, managers should pay more attention to features that gained low assessment (from and below the average) are "Loyal patron of this brand", "This brand is the first \& prefer choice" and "Encourage others to buy this brand".

To policy makers in the fields related to seafood sector: First, policy makers in the field of the seafood sector should build a fairly competitive market for all participants by issuing the legal framework, regulations and conduct suitable measures to protect the market and support its smooth operation.

Second, policy makers in the field of the seafood sector should set up a plan to speed up consumption of seafood in Ho Chi Minh City, providing that the benefits of eating seafood will be publicly distributed to the people.

To administrators at various levels in ho chi minh city: First, administrators at various levels must keep the political and social stability for the economy. Therefore, Ho Chi Minh City will become a promising market where customers can benefit from fair competition.

Second, administrators at the city level should build a masterplan to develop supermarkets in Ho Chi Minh City. Through this development, seafood products can be easily delivered to the people of the city.

To customers at supermarskets in ho chi minh city: First, customers should select brands that bring qualifications such as good packing design, leading, confidence of delivery, affordable, affinity, quality, easy to process, durable, exact as advertised, nutritional, safe,

\begin{tabular}{|c|c|c|c|c|}
\hline Factor & Question & Mean & Std. Dev. & N \\
\hline C3.6.1 & I will choose this brand again & 3.71 & 0.737 & 396 \\
\hline C3.6.2 & This brand is the best choice & 3.66 & 0.921 & 396 \\
\hline C3.6.3 & Loyal patron of this brand & 3.44 & 0.829 & 396 \\
\hline C3.6.4 & Recommend this brand to others & 3.69 & 0.733 & 396 \\
\hline C3.6.5 & Intention to purchase this brand again & 3.72 & 0.690 & 396 \\
\hline C3.6.6 & This brand is the first \& prefer choice & 3.40 & 0.810 & 396 \\
\hline C3.6.7 & Speak positively about this brand & 3.69 & 0.683 & 396 \\
\hline C3.6.8 & Encourage others to buy this brand & 3.60 & 0.731 & 396 \\
\hline & Average & 3.60 & & \\
\hline
\end{tabular}

Table 11: Statistical summary of Brand Loyalty. 
Citation: Nguyen, Thuy TT, Thanh Q (2016) An Analysis of Brand Personality on Brand Loyalty in Frozen Seafood Supermarkets in Ho Chi Minh City. J Aquac Res Development. 7: 412. doi:10.4172/2155-9546.1000412

Page 8 of 8

original, friendly, sincerity proven, style, suitable, good passion, being difference, up to date, independent, and unique.

Second, customers should be wise and prudent ones by choosing valuable foods in their daily life. Frozen seafood is one of the best foods they can afford. Seafood is not only good for the current consumers but also for future generations.

\section{References}

1. FTA (2009) Vietnam regional differences - HCMC, Hanoi, Central (Danang), Mekong Delta (Can Tho) in brand attitudes, service requirement, price sensitivity, channel preference and A\&P preferences.

2. Davies G, Chun R (2003) The use of metaphor in the exploration of the brand concept. Journal of Marketing Management 19:45-71.

3. Kassarjian H (1971) Personality and consumer behavior: A review. Journal of Marketing Research 8: 409-418.

4. Aaker J (1997) Dimensions of Brand Personality. Journal of Marketing Research 34: 347-356.

5. Keller K (1993) Conceptualizing, measuring and managing customer-based brand equity. Journal of Marketing 57: 1-22.

6. Belk R (1988) Possessions and the Extended Self. Journal of Consumer Research 2: 139-138.

7. Malhotra N (1988) Self concept and product choice: an integrated perspective. Journal of Economic Psychology 9: 1-28.

8. Kleine R, Kleine S, Kernan J (1993) Mundane consumption and the self: a social-identity perspective. Journal of Consumer Psychology 2 209-235.

9. Biel A (1993) Converting image to equity in Brand equity and advertising. Hillsdale, NJ: Lawrence Erlbaum Associates.

10. Azoulay A, Kapferer J (2003) Do brand personality scales really measure brand personality? The Journal of Brand Management 11: 143-155.

11. Colucci M, Montaguti E, Lago U (2008) Managing brand extension via licensing:
An investigation into the high-end fashion industry. International Journal of Research in Marketing 25: 129-137.

12. Madden J, Fehle F, Fournier S (2006) Susan Brands Matter: An Empirical Demonstration of the Creation of Shareholder Value Through Branding. Journal of the Academy of Marketing Science 34: 224-235.

13. Warlop L, Ratneshwar S, Van O (2005) Distinctive brand cues and memory for product consumption experiences. International Journal of Research in Marketing 22: 27-44.

14. Plummer J (2000) How personality makes a difference. Journal of Advertising Research 40: 79- 84.

15. Van Rekom J, Jacobs G, Verlegh $P$ (2006) Measuring and managing the essence of a brand personality. Marketing Letters 17:181- 192.

16. Leary M, June P (2003) Handbook of Self and Identity. (2ndedn) Guilford Press ,New York.

17. Tesser A, Paulhus D (1983) The definition of self: Private and public selfevaluation maintenance strategies. Journal of Personality and Social Psychology 44: 672-682.

18. Jacoby J, Chestnut R (1978) Brand Loyalty: Measurement and Management.: John Wiley \& Sons, New York.

19. Brown GH (1952) Brand loyalty - fact or fiction? Advertising Age 9: 53-55.

20. Cunningham R (1961) Customer Loyalty to Store and Brand. Harvard Business Review 39:127-137.

21. Ratchford B (1987) New insights about the FCB GRID. Journal of Advertising Research 27.

22. Venkateswaran P, Binith M, Geetha U, Ananthi N (2011) A Study on Brand Personality Dimensions and Brand Loyalty towards Raymond Brand. Journal of Marketing \& Communication 7: 21-30.

23. Pallant J (2005) SPSS Survival Manual. A step-by-step guide to data analysis using SPSS for Windows (Version 12). Crows Nest NSW 2065, Allen \& Unwin, Australia. 